\title{
Keterlambatan Pubertas
}

\author{
Syamsul Azwar
}

\begin{abstract}
Keterlambatan pubertas merupakan masalah penting pada anak karena dapat terjadi keterlambatan pertumbuhan dan maturasi tulang. Diagnosis keterlambatan pubertas ditegakkan berdasarkan anamnesis, pemeriksaan fisik, laboratorium dan radiologi. Pengobatan utama keterlambatan pubertas pada pria dengan pemberian testoteron dan pada wanita pemberian estrogen. Selain pengobatan hormonal pendekatan psikologi juga diperlukan.
\end{abstract}

Kata kunci: pubertas, gonadotropin, pengobatan testoteron dan estrogen.

P

ubertas merupakan salah satu periode dalam proses pematangan seksual dengan hasil tercapainya kemampuan reproduksi. ${ }^{1,2}$ Pubertas ditandai dengan munculnya karateristik seks sekunder dan diakhiri dengan datangnya menars pada anak perempuan dan lengkapnya perkembangan genital pada anak laki-laki. ${ }^{1,3}$ Usia awal pubertas pada anak laki-laki berkisar antara $9-14$ tahun dan perempuan berkisar $8-13$ tahun. ${ }^{1,4}$

Pubertas dikatakan terlambat apabila perubahan fisik awal pubertas tidak terlihat pada usia 13 tahun pada anak perempuan dan 14 tahun pada anak laki-laki. ${ }^{1,5,-9}$ Evaluasi terhadap kemungkinan adanya keterlambatan pubertas juga harus dilakukan apabila lebih dari 5 tahun rentang antara tanda pertama pubertas dan menars atau lengkapnya perkembangan genital pada anak laki-laki. ${ }^{1,5}$ Berdasarkan status gonadotropin kelainan ini dibagi dalam hypergonadotropin hypogonadism dan hypogonadotropin hypogonadism.

Angka kejadian keterlambatan pubertas belum diketahui secara pasti. Anak laki-laki lebih sering dibanding anak perempuan. Keterlambatan pubertas pada anak perempuan biasanya disertai adanya kelainan patologis. ${ }^{1}$ Sampai saat ini belum ada laporan angka kejadian keterlambatan pubertas di Indonesia, oleh karena banyak kasus keterlambatan pubertas yang tidak dilaporkan. ${ }^{1}$

\footnotetext{
Alamat korespondensi:

Dr. Syamsul Azwar.

Bagian Ilmu Kesehatan Anak FK USU/RS HAM

Jalan Bunga Lau No. 17, Medan.

Telepon: (061) 8361721, Fax,: (061) 8361721.
}

Penyebab keterlambatan pubertas sangat bervariasi mulai dari kelainan kromosom, genetik, penyakit kronik atau tumor pada kelenjar hipofisis atau hipothalamus sampai yang tidak diketahui penyebabnya. ${ }^{1,6-8}$

Kecurigaan awal terhadap adanya keterlambatan pubertas apabila karakteristik seks sekunder belum terlihat pada waktunya. ${ }^{1,6}$ Diagnosis ditegakkan berdasarkan anamnesis, pemeriksaan fisik, laboratorium dan radiologi. Pendekatan awal terhadap kasus kerlambatan pubertas adalah penentuan status gonadotropin dan pemeriksaan usia tulang. Keterlambatan pubertas harus di terapi segera karena pasien akan mengalami keterlambatan maturasi tulang dan pertumbuhan dan tanpa pengobatan akan memperlihatkan adanya perawakan pendek, gambaran fisik seperti anak-anak dan tidak terlihatnya gambaran karakteristik seks sekunder. ${ }^{4,12}$ Keadaan ini juga dapat menyebabkan terjadinya gangguan psikologi. ${ }^{1,12}$ Makalah ini membicarakan secara umum mengenai keterlambatan pubertas dengan penekanan pada diagnosis dan penatalaksanaan.

\section{Penyebab}

Penyebab keterlambatan pubertas dibagi dalam 2 kelompok berdasarkan status gonadotropin; yaitu hypergonadotropin dan hypogonadotropin. Pada hypergonadropin kelainan terjadi didaerah perifer disebabkan kegagalan gonad sedangkan pada hypogonadrotropin kelainan dapat terjadi pada susunan saraf pusat (SSP), hipotalamus, atau hipofisis (Tabel 1). 
Tabel 1. Etiologi keterlambatan pubertas ${ }^{1}$

1. Keadaan hipergonadotropin ( kegagalan gonad primer)

a. Kromosomal, kelainan genetik dan sindrom: defek sintesis enzim androgen, sindrom insensitivitas androgen partial dan komplet, sindrom 46.XX, 47.XYY, galaktosemia. Sindrom Klinefelter (47.XXY), campuran 45. X/46, disgenesis $\mathrm{XY}$, sindrom multipel X-Y, sindrom multipel Y, distropia miotonik, sindrom Noonan, disgenesis gonadal $46 \mathrm{XY}$ murni, defisiensi $\alpha$ reduktase, sindrom ovari resisten, sindrom Turner.

b. Akuisita: autoimun, kemoterapi, infeksi (coxsackie, mumps), pembedahan, torsi, traumatik.

2. Keadaan hipogonadotropin (hipothalamus-hipofise).

a. Defisiensi hipothalamus-hipofise

Defisiensi gonadotropin

Hanya LH (sindrom eunuch fertile)

LH dan FSH

- Akuisita [autoimun, iradiasi kranial, penyakit granulamatosa, hemosiderosis (talasemia), penyakit sikle cell].

- Kongenital, genetik, sindrom (sindrom Alstrom, sindrom Borjenson-Forsman- Lehmann).

- Sindrom CHARGE, sindrom idiopatik Kallmann, sindrom Laurence- Moon-Bardet-Beidl, sindrom multipel lentigines, sindrom Prader Willi, defek prosencepalon (berhubungan dengan sindrom incisor sentral, cleft lip palate, midfacial cleft, displasia septooptik).

b. Endokrinopati (meliputi: defisiensi gonadotropin): hipopituarism (idiopatik atau sindrom sella sekunder, inflamasi, disgenesis hipofise, radiasi, kista rathke pouch, pembedahan, trauma, tumor (kraniofaringioma, adenoma hipofise, proklatinoma).

3. Keterlambatan atau penundaan fungsi

- Constitutional delay of growt and puberty

- Penyakit kronik [kardia, hematologik (penyakit sikle cell)] keganasan, pulmonal (cystic fibrosis, ginjal)

- Penyalahgunaan obat

- Pengeluaran energi yang berlebihan pada latihan

- Obesitas eksogen

- Endokrinopati: diabetes melitus, defisiensi growth hormon, kelebihan glukokortikoid, hiperproklatinemia, hipotirodisme

- Malnutrisi

- Kelainan psikiatri (anoreksia nervosa, psikososial)

\section{Manifestasi Klinik}

Gambaran klinis pertama yang terlihat pada keterlambatan pubertas apabila karakteristik seks sekunder belum terlihat pada waktunya. Pada umumnya perkembangan seksual anak perempuan dimulai pada usia 8 tahun dan pada anak laki-laki usia 9,5 tahun. Pada constituional delay, fisik tampak normal namun alat genital tidak tampak berkembang. Pada anak perempuan harus dicurigai adanya keterlambatan pubertas apabila payudara belum berkembang pada usia 13 tahun, waktu antara perkembangan payudara dan menstruasi lebih dari 5 tahun atau tidak berkembangnya rambut pubis pada usia 14 tahun dan menstruasi tidak datang pada usia 16 tahun. Pada anak laki-laki harus dicurigai adanya keterlambatan pubertas apabila pembesaran testis tidak terjadi pada usia 14 tahun, tidak berkembangnya rambut pubis pada usia 15 tahun atau lebih dari 5 tahun baru terjadi pembesaran alat genital. ${ }^{1,6,8}$

Gambaran klinis lain ditandai dengan adanya perawakan pendek. Beberapa kasus memperlihatkan imaturitas pada proporsi tubuh (rasio tinggi badan atas dan bawah) lebih besar dibanding dengan normal, pada pertumbuhan normal tinggi badan bawah lebih panjang. Gambaran lain sesuai dengan penyakit yang mendasarinya seperti adanya anosmia atau hiposmia pada sindrom Kallmann's. ${ }^{1,6-8}$

\section{Diagnostik}

\section{Riwayat penyakit}

Beberapa hal yang perlu ditanyakan dalam anamnesis 
ialah riwayat kecepatan peningkatan tinggi badan, berat badan dan penurunan testis, riwayat keluarga dengan gangguan pubertas. Apakah ada dijumpai gejala-gejala gangguan SSP, riwayat trauma, anomali atau infeksi SSP, riwayat mendapat kemoterapi, radioterapi atau riwayat pembedahaan. Riwayat mendapat pengobatan dengan glukokortikoid.

\section{Pemeriksaan fisik}

a. Pemeriksaan tinggi badan, berat badan, perbandingan tinggi badan atas dan bawah. Rasio antara tinggi badan atas dan bawah. Rasio yang lebih tinggi menunjukan adanya imaturitas atau keterlambatan. ${ }^{1,7,8}$ Pada orang kulit hitam rasio yang normal adalah 0,88 .

b. Pemeriksaan maturitas seksual atau pubertal stage; Tingkat maturitas seksual dapat ditentukan dengan menggunakan skala Tanner. Berdasarkan perkembangan payudara, rambut pubis dan perkembangan genital, Tanner membagi tingkat maturitas seksual dalam 5 tingkatan. Tingkat I (prepubertas) sampai tingkat $\mathrm{V}$ (dewasa). Dikatakan pubertas apabila berada pada tingkat II skala Tanner. ${ }^{2,7,8,13,14}$ Pada anak perempuan di lakukan pemeriksaan perkembangan payudara dan rambut pubis. Pada anak laki-laki dinilai perkembangan alat genital, ukuran penis, volume testis dan konsistensi testis. Pemeriksaan lokasi testis juga perlu dilakukan (skrotal, inguinal atau tidak turun). Tanda pubertas yang lainnya juga perlu di lihat seperti adanya akne dan pigmentasi kulit. ${ }^{2,7,15}$

c. Pemeriksaan lain yang diperlukan ialah pemeriksaan funduskopi, pemeriksaan fungsi tiroid dan pemeriksaan status neurologi. ${ }^{1,7,8}$

\section{Pemeriksaan laboratorium $1,7,8,16,17,18,19$}

a. Pemeriksaan kadar follicle stimulating hormone(FSH) dan luteinizing hormone (LH). Pemeriksaan laboratorium awal adalah menentukan status hormon gonadotropin. Pemeriksaan FSH, LH dan steroid seks merupakan pemeriksaan minimal yang harus dilakukan. Kadar FSH dan LH berbeda pada usia, seks, dan tingkat perkembangan.

b. Uji stimulasi gonadotropin realising hormone $(\mathrm{GnRH})$. Uji stimulasi GnRH dilakukan untuk mengevaluasi fungsi kelenjar hipofisis. Uji ini dapat membedakan kelainan pada SSP atau perifer.

c. Pemeriksaan testoteron dan estradiol.

d. Uji stimulasi human chorio gonadotropin (HCG). Uji stimulasi HCG diperlukan jika kedua testis tidak teraba, dicurigai adanya testikular defek, atau kadar gonadotropin tidak meningkat.

e. Pemeriksaan sekresi growth hormone $(\mathrm{GH})$ dan fungsi tiroid. Pemeriksaan ini dilakukan jika kecepatan pertumbuhan subnormal.

\section{Pemeriksaan radiologi}

Pemeriksaan radiologi penting untuk menentukan umur tulang dengan pemeriksaan pusat penulangan pada tangan dan pergelangan tangan. Tingkat osifikasi dinilai dan dibandingkan dengan nilai rata-rata usia dan seks, kemudian usia tulang di bandingkan dengan usia biologik. Pemeriksaan lain adalah CT-scan kepala dan MRI untuk melihat daerah hipothalamus. ${ }^{1,6-8}$

\section{Tata laksana}

Tatalaksana keterlambatan pubertas meliputi pengobatan pada kegagalan pertumbuhan, perawatan pendek dan terhadap imaturitas psikologik atau emosional. ${ }^{1}$

Pengobatan laki-laki dengan adalah pemberian testoteron enanthathe atau cypionat. Dosis awal bervariasi tergantung pada usia dan maturitas pasien dan kecepatan perkembangan pubertas. Pemberian dosis tinggi dapat menstimulasi perkembangan lebih cepat dan sebaliknya dosis rendah dapat menstimulasi perkembangan lebih lambat. Testoteron diberikan dalam bentuk injeksi intramuskular dengan dosis antara 50-100 mg setiap 4 minggu selama 4-6 bulan. Dosis penuh testoteron tidak boleh melebihi $100 \mathrm{mg} /$ minggu, diberikan dalam interval 2 minggu atau 3 minggu. ${ }^{1,19,20}$ Injeksi $400 \mathrm{mg}$ setiap 4 minggu tidak direkomendasikan. ${ }^{1}$ Efek pengobatan biasanya sudah terlihat setelah 1 bulan pengobatan. Keberhasilan pengobatan dapat dinilai secara klinis dan laboratoris. Setelah 1 bulan pengobatan biasanya mulai terlihat peningkatan maturasi seksual atau peningkatan skala Tanner. Richman RA. ${ }^{20} \mathrm{dkk}$ melakukan pengamatan setelah 3, 7 dan 18 bulan pengobatan testoteron enanthate dengan dosis $50 \mathrm{mg} / \mathrm{bulan}$. Ditemukan adanya peningkatan volume testis dari $5,9 \pm 2,8 \mathrm{ml}$ menjadi $11,3 \pm 2,7 \mathrm{ml}$ dan peningkatan dari 
prepubertas menjadi tingkat 3 dan 4 skala Tanner, serta peningkatan kecepatan tinggi. Pengobatan lain adalah pemberian oxandrolon dengan dosis $0,05-0,1 \mathrm{mg} /$ $\mathrm{kgBB} /$ hari selama $3-6$ bulan atau fluoxymesteron dengan dosis $2-3 \mathrm{mg} / \mathrm{m}^{2} /$ hari selama $3-6$ bulan. ${ }^{8,15,21,19}$ Fluoxymesteron merupakan androgen oral sintetik. Pemberian HCG dengan dosis $500-1000$ unit intramuskular 3 kali seminggu selama $1-2$ bulan juga direkomendasikan. Terapi HCG hanya diberikan jika fungsi sel leydig normal. ${ }^{8}$

Pada anak perempuan pengobatan awal dengan pemberian estrogen dosis rendah selama $6-12$ bulan. Estrogen dosis rendah yang diberikan adalah premarin $0,3 \mathrm{mg} /$ hari atau ethinyl estradiol $0,02 \mathrm{mg} /$ hari atau 0,05 mg secara transdermal 1-2 kali seminggu sudah memadai sebagai terapi awal. Sebagai alternatif pemberian estrogen harian atau bentuk transdermal selama 3 minggu pertama (21 hari) dilanjutkan dengan pemberian progresteron 10 hari. Progresteron yang diberikan adalah medroxyprogesteron 5 atau $10 \mathrm{mg} / \mathrm{hari}$ atau norethinedrone $5 \mathrm{mg} /$ hari. Dosis estrogen dapat bervariasi tergantung dari kecepatan atau perkembangan pubertas. Dosis ethinyl estradiol 0,02-0,10 mg/hari, konjugate estrogen $0,3-1,25 \mathrm{mg} / \mathrm{hari}$ atau bentuk transdermal 0,05 atau $0,10 \mathrm{mg} /$ hari. $^{1}$

Pendekatan psikologik diperlukan pada kasus yang mengalami gangguan psikologik. Dukungan psikologik diperlukan untuk meningkatan kepercayaan diri. Orang tua juga harus diberikan dukungan psikologik, serta hubungan orang tua anak harus lebih ditingkatkan. ${ }^{1,12}$

\section{Daftar Pustaka}

1. Lee PA. Disorders of puberty. Dalam: Lifshitz F, penyunting. Pediatric endocrinology. Edisi ke-3. New York: Marcel Dakker; 1996. h. 175-93.

2. Rebar RW. Puberty. Dalam: Bercks JS, Adashi EY, Hillard PA, penyunting. Novak's gynecology. Edisi ke-12. Philadelphia : William \& Wilkins; 1996. h. 771-92

3. Henneberg CM, Vizamons B. The duration of puberty in girls is related to the timing of its onset. J Pediatr 1997; 131:618-21.

4. Beckmann CRB, Ling FW, Barzansky BM, Bates GW, Herbert WND, Laube DW, dkk. Obstretics and gynecology. Edisi ke-2. Philadelphia: William \& Wilkins; 1995. h. 268-72.

5. Saenger P. Delayed puberty. When to wake the bugler. J Pediatr 1998; 133:724-6.
6. Children's Medical center of Dallas. Delayed puberty. Diperoleh dari URL : http/www. childrens.com/health info dysplay. cfm.id: 426 and main: 406

7. Kulin HE. Normal pubertal development. Dalam: Rudolph AM, Hoffman JIE, Rudolph CD, penyunting. Rudolph's pedriatics. Edisi ke-20. Philadelphia: Prentice Hall International; 1976. h. 1800-2.

8. Felig P, Bareter JD, Broadus AE, penyunting. Endocrinology and metabolism. Edisi ke-2. New York: Mc GrawHill Book; 1987. h. 869-951.

9. Kapolwitz P. Delayed puberty in obese boys: Comparison with constitutional delayed puberty and response to testorone therapy. J Pediatr 1998; 133:745-9.

10. Tse WY, Buyakgebiz A, Hindmarsh PC. Long term outcome of oxandrolone treatment in boys with constitutional delay of growth and puberty. J Pediatr 1990; 117:588-90.

11. Copeland KC, Paunien L, Sizonenko PC. The secretion of adrenal androgens and growth patterns of patients with hypogonadotropic hypogonadism and idiopatic delayed puberty. J Pediatr 1997; 91:985-90.

12. Susman EJ, Finklestein JW. Churchill UM. The effect of sex hormonal replacement therapy on behaviour probelms and moods in adolescent with delayed puberty. J Pediatr 1998; 133:521-2.

13. Needlman RD, Adolescence. Dalam: Behrman RE, Kliegman RM, Arvin AM, penyunting. Nelson textbook of pediatrics. Edisi ke-15. Philadelphia: Saunders; 1976. h. 58-63.

14. Markum AH, Ismael S, Alatas H, Akib H, Firmansyah A, Sastroasmoro S, penyunting. Buku Ajar Ilmu Kesehatan Anak. Jilid I. Jakarta: FK-UI Press; 1.

15. Londell RD, Foster MB, Dave KC. Disorders of puberty. Diperoleh dari URL: http://www.aafd.arg 1990700 ap/ 209.htm.

16. Ehrmann DA, Rosenfield AL, Cuttler L. A new test of combined pituitary testicular function using the gonadotropin realising hormone agonist nafarelin in the differentiation of gonadotropin deficiency from delayed puberty. Pilot studies. J Clin Endocrinol Metab 1989; 69:963-7.

17. Kerrigan JR, Rogol AD.The impact of gonadal steroid hormone action on growth hormone secretion during childhood and adolescent. Endocrine review, 1992; 13:281-95.

18. Partsch CJ, Dreyer G, Gosch A. Longitudinal evaluation of growth, puberty and bone maturation in children with Williams syndrome. J Pediatr 1999; 134:829 .

19. August GP. Puberty: Normal mechanism. Dalam: Bell JJ, August GP, Carpenter TD, penyunting. A current review of pediatric endocrinologi. Edisi ke-3. Washington DC; 1993. h. 45-63.

20. Richman RA, Kirsch LR. Testoterone treatment in adolsecent boys with constitutional delay in growth and development. N Engl J Med 1988; 319:1563-7.

21. Strickland AL. Long term result of treatment with low dose fluocymesterone in constitutional delay of growth an puberty and in genetic. Diperoleh dari URL : http:/ lwww.com/health. 